\title{
Sciendo
}

\section{Quality Assurance in Multicultural University - People's Friendship University of Russia}

\author{
Diana Spulber \\ Professor People's Friendship University of Russia \\ Email:spulber_d@pfur.ru
}

Doi: $10.2478 /$ gssfj-2020-0005

\begin{abstract}
In a knowledge-based economy, higher education becomes the most important factor of national competitiveness. It is in the Universities that the most high-performance human capital is formed, knowledge and innovation are produced. Therefore, the last decades are characterized by the growth of global competition in the field of bigher education educations. And for the purpose the President of Russian Federation in his plan for 2024 (presidential Decree No. 204 of May $7^{\text {th }}$, 2018) has been underlined the global goals and objectives set for the spheres of education and science for the next five years. Among them, in particular, is ensuring the competitiveness of Russian education at the world level and Russia's entry into the top five countries in the world in research. Another purpose indicated for education is enrolment of foreigner's students. The Peculiarity of PFUR is that in this University is mainly foreign students

Peoples ' Friendship University of Russia is a unique University, a major international-oriented educational and research institution. In the walls of the Peoples 'Friendship University of Russia annually are trained citizens from 152 countries.

The article will analyse the System of HEI Quality Assurance in Russia and development in the last years, will be analysed the interview data of VTSIOM in field of Quality of Russian Education. The Quality Assurance System at the PFUR will be illustrated starting from Boards, Procedures and arriving to indicators and how these indicators have been acbieved.
\end{abstract}

Key words Education in Russian Federation, Quality Assurance in Russia, Quality Assurance at PFUR

\section{Introduction}

Modern society in the era of globalisation imposes new requirements to the organisation, management and, most importantly, to the quality of education. The idea of Alvin Tofler that wrote in 1971 that the education must shift into the future tense and that modern civilisation challenges all our old initial attitudes is still actual today. Each historical period has a specific time-bias, rapid exchanges that need time-bound replies deeply linked with the society request. In this period, when the changes happen fast, when physical distance does not represent a barrier anymore, the old ways of thinking, the old formulas can be an impediment to be competitive and to reach new horizons. The world that is emerging with high speed from the collision of new values and technologies, new geopolitical relations, new lifestyles and ways of 
communication, requires completely new ideas and analogies, classifications and concepts.

The main competitive advantage of a higher education institution today is the quality of education since its high level is an incentive for consumers to choose an educational institution where they can get this service.

The university also has a scientific and cultural mission. It produces new scientific knowledge and critically assesses those generally accepted by the academic community, creates, through members of national and international value. In the exercise of these functions, it benefits from academic autonomy and follows the progress of human knowledge, process it is hard to predict. These high goals of the university must harmonise with the mission of educating and training the younger generation.

The quality of educational services is a set of properties and characteristics that give them the ability to meet the stipulated or assumed needs. Thus, the main task of higher education institutions is not only to develop students ' academic knowledge but, above all, their ability to work, live and adapt in a rapidly changing world.

\section{Quality of education theoretical background}

The concept of "quality" is an expanding category that includes aspects ranging from the quality of products and services, labour, health, education, culture, environment to the quality of life. Thus, the category "quality" becomes philosophical, and the problems associated with it affect and transform all spheres of society.

In the philosophical understanding of the term "quality", proceed from the definition of quality as an essential feature, a property that distinguishes one object from another. From the production approach, quality is a set of essential consumer properties of a product or service that are significant for the consumer. In a metaphorical sense," products " of the school are graduates who have an education of the best or worst quality, more or less corresponding to the needs of society and the individual, established norms, requirements, standards. The University product is the graduate student his knowledge, his qualities his employability in the work market.

Quality can manifest itself in or be lacking in any aspect of a firm's activity, institutions or even human communities. There is a multitude of definitions of the concept of quality, each having a greater or lesser degree of suitability with the activity of a higher education institution.

J. M. Juran says that the quality of a product means its ability to be used (good for use)".

"Good to use" is a label that is undoubtedly applicable to all products of the activity and also the knowledge is a "good to use". 
If we apply this definition to Higher Education, we can say that the University good to use is the competence of graduates, the results of scientific research, expertise and consultancy. In this vision, the quality represents the outputs adequacy (skills, knowledge) to the customer requirements (if defined) or of the specific socio-economic area to which the product or service is addressed. A. V. Feigenbaum " the set of characteristics of the service or product by which the product or service meets the customer's expectations in use".

If we apply this definition to Higher Education, we can say that it could be a set of student's skills that should meet the work market and society's expectations.

Feigenbaum describes quality as a "managerial tool" assuming four stages:

setting quality standards; assessment of compliance with these standards; action in case of deviation from standards; improving these quality standards. The dynamism of the market for educational services and scientific research also induces the trend of

strengthening the entrepreneurial character of the university's management function; thus appears in necessary chip a comparison between the functioning of the University Institution and the principles of operation of an enterprise. The new approach claims a strategy and managerial structures appropriate, the introduction of a proper system for the selection and training of management, ensuring a high degree of overlap between responsibility and competence in all levels of management.

G. Taguchi: "the minimum loss to the company by exiting the product on the market."

In Taguchi's view, the losses mentioned can be: of the producer organisation by costs of non-quality passed on internally (waste repair defects under warranty and those resulting from damage market image of the manufacturer); non - quality costs imposed on the customer by the low product performance. This latter definition is highly relevant from the perspective of Higher Education.

In the case of state-funded higher education institutions, there is a peculiarity worrying: both the internal costs of non-quality, reflected by the inefficient use of resources allocated, as well as external ones (indicated by unemployment, incompetence of teachers in primary and environmental education, the inability of researchers and consultants to create value the company.

When defining the concept of "quality of education", there are four main factors: the quality of educational content; the quality of teaching; the quality of information and communication educational technologies, including the quality of electronic learning tools developed on their basis, and the quality of educational results.

The quality of education is understood as the quality of the educational process, which reflects the degree of compliance of educational results 
(achievements) of students and the conditions for ensuring the educational process with regulatory requirements, social and personal expectations and includes the following components: quality of the educational program; quality of the educational process organisation (educational technologies, forms, methods, methods of training, forms of training organisation); quality of management of educational systems and processes (management technologies in education); quality of the potential of the scientific and pedagogical staff involved in the educational process; quality of resource support (material and technical, educational and methodological support); the quality of moral, spiritual, and moral education in the process of socialisation of the individual; quality of medical care, nutrition, sports and recreation work; quality of partner interaction with the family and society; quality of students ' potential; the quality of knowledge.

As stated bellow if we shift the use of product quality from the economic world to the academic world, we can state that Higher education institutions are organisations, providing professional and science service. The "products" offered by higher education are competence and knowledge, intangible products, supplied to society in various forms:

training of specialists in specific areas provided to the community by transfer of skills through graduates.

Fundamental and applied scientific research, consultancy, expertise supplied to society by widening

the horizon of human knowledge, transfer of competence to socio-economic organisations, to generate new and increase their competitiveness.

Involvement of members of the academic community in the life of society supplied to society by transfer of competence achieved through direct participation in local, regional community, national and international organisations.

\section{Quality of Education in the Russian Federation}

Russia's involvement in the processes of globalisation is manifested, in particular, in the inclusion of Russian universities in the international competition for the provision of higher education services. In conditions of increasing mobility of the country's younger generation, applicants can choose to study abroad. In turn, for Russian universities, the market of potential consumers of their services is expanding to the scale of the entire planet.

The primary task of education in the current century is to promote the formation of civil society of equal opportunities, political and economic freedoms. It is education that should balance the standard opportunities of various representatives of society entering into independent life. 
More than 16 years ago, 29 European States signed the Bologna Declaration, which sets out the common goals and principles of creating a single European education system. The main goal of the Bologna Declaration is to improve the quality of higher education.

The Bologna Declaration sets out the directions for the formation of a market model of higher education and the transformation of national higher school systems. The main ones are the transition to two-level programs (bachelor's, master's); reduction of the standard period of study; changes in the content of education taking into account the interests of employers; changes in the structure of the organisation of doctoral programs; development of distance and continuing education, etc. Russia, like many economically developed countries, is also a participant in the Bologna process and for many years the country has been adapting its higher education system to the Bologna system. Implementation of the Bologna process in Russia drew to the exchange of Higher Education architecture.

The main strategic goal of the state policy of education is to increase access to quality education following the requirements of innovative development of economy and contemporary needs of society. Thus, the main task of a higher education institution is it becomes not only the formation of students ' academic knowledge but, first of all, the ability to work, live and adapt a changing world quickly.

The modernisation of education in Russia is a long, multidimensional process that has created many problems and is not without reason, causing criticism and rejection among a significant part of the country's population. The situation is complicated by the fact of a prolonged transformation of the socio-economic system, the transition to market relations, which negatively affected the standard of living of the absolute majority of the population.

The rejection of innovation by the traditions and standards of the classical Russian system of higher education, which has incorporated the achievements of the Soviet higher school with its traditional Russian classical orientation to the fundamental and axiological component, remains a serious problem for the modernisation of education in Russia. Accordingly, one of the most critical problems of the modern Russian higher education system is the search and implementation of optimal forms of interaction between traditional and innovative technologies in higher education.

Nether less the socio-historical barriers the Russia policy in HE was oriented to the implementation of the project "5-100" Its essence is to ensure that by the end of 2020 at least five Russian universities will be among the top 100 leading universities in the world.

It is a long process and requires different radical changes in HEI's Architecture. (Spulber, 2005)

In 2000, the Russian Federation adopted the national education doctrine by government decree, which established the priority of education in the 
country's state policy and the expected results of education development until 2025. The doctrine sets out strategic goals for education, including overcoming the socio-economic and spiritual crisis and restoring Russia's status in the world community as an essential power in the sphere of education, science, and culture. ${ }^{\wedge}$

The Federal program for the development and reform of education defines specific measures for its modernisation and corresponding resources. In these key documents, a significant role is assigned to the quality of education in Russian universities.

In 2009 was done another important step in the reform process of Higher Education in Russian Federation by the Federal Law of February 10, 2009, N 18-FL "Amendment to certain legislative acts of the Russian Federation on the activities of Federal universities" After this year a new paradigm appears in Russian HEIS and especially Federal University and National Research University. The category "national research University" was assigned to universities based on competitive selection, in which they could participate on their own initiative. However, the process of creating the FU and NRU was carried out in the absence of a formulated state concept of regional policy in the field of higher education. Without going into details of the differences between FU and NRU from ordinary universities, we note that the main expected results from their creation were stated as follows: increasing the level of international recognition of Russian science and education (achieving a world-class Russian education); solving the problem of access to quality education in remote areas of the country; ensuring a system-forming role in regional systems of higher education institutions.

The need to ensure the quality of educational activities is stipulated in article 95.2 of Federal Law No. 273-FZ of December 29, 2012 "on education in the Russian Federation". Criteria and indicators of education quality established by the Federal regulations (Ministry of education of Russia from December 5, 2014 № 1547 "On approval of the indicators of General evaluation criteria of quality of educational activity of organisations carrying out educational activities»). In the Russian Federation, Federal law No. 273-F3 of 29.12.2012 defines the concept of quality of education. This is a complex peculiarity of the "educational activities and training of the student, expressing the degree of their compliance with Federal state educational standards, Federal state requirements and(or) needs physical or legal $\mathrm{OO}$ entity in whose interests educational activity is carried out, including the degree of achievement of the planned results of the educational program".

By the same law, the characteristics of FU and NRU were described in the concept of creation and state support for the development of Federal universities (2009) and the concept of creating a network of national research universities (2009). Subsequently, the new categories of higher education 
institutions were reflected in article 24 of the Federal law "Education in the Russian Federation", adopted in 2012.

The Appendix to the Order of the Ministry of education and science of the Russian Federation dated 10.12.2013 № 1324 "on approval of performance indicators of organisations subject to self-examination" contains indicators for higher education organisations.

These indicators are United in the following five groups: educational, research, international, financial and economic activities, infrastructure. In total, more than 70 indicators are provided.

After 2012 Law about the Quality in Higher education the number of universities has decreased by almost a third Department concluded that the task was successfully completed. However, the question was how to increase the quality.

In the current conditions, universities are forced to fight for students, because the supply of educational services in many places has long exceeded the demand. The last years, in order to counteract this trend, the Ministry of education and science policy has been aimed at reducing the number of branches and head universities themselves. The requirements for the state accreditation procedure have been tightened, and various monitoring measures are being introduced to determine the effectiveness of higher education institutions. At the same time, every university is interested in a high-quality student, since the quality of the applicant directly depends on the quality of the student. All Russian universities conduct planned career guidance in order to attract talented young people

In recent years, high-quality education is also inextricably linked with the development of modern educational technologies. Today, teachers need a creative approach, which is expressed in the search for new techniques and methods of teaching, in particular, in the active use of interactive teaching methods (discussion, game, training, etc.) and modern educational technologies, for example, actively promoted in the educational sphere of the project method of teaching. Only with a skilful combination of various forms and methods of training can you arouse the interest of current students in their subject, and, as a result, their stable motivation for educational and future professional activities.

In the Russian Federation the Quality evaluation is a long process.

External evaluation procedures for the quality of educational programs:

- different types of accreditation and certification;

* independent examination of educational programs, including with the involvement of international experts.

Accreditation is the process of recognising the quality of education following the norms and quality standards of the accrediting organisation. If these standards are set by the state (through Federal state educational standards), then accreditation is called state. 
In the Russian Federation there are several types of accreditation. All the types of accreditation are indicated and well described in the Federal law 29.12.2012 N 273-" Education in the Russian Federation modified on 02.06.2016.

Public accreditation refers to the recognition of the level of activity of an educational organisation that meets the criteria and requirements of Russian, foreign and international organisations. The procedure for conducting public accreditation, forms and methods of evaluation during its conduct, as well as the rights granted to an accredited organisation engaged in educational activities, are established by the public organisation that conducts public accreditation. (Paragraph 4, Article 96 of Federal Law No. 273) of the basic professional educational programmes of basic vocational training and (or) additional professional programs is a recognition of the quality and level of training of graduates who have mastered the educational program of each organisation performing educational activities that meet the requirements of professional standards, labour market requirements specialists, workers and employees of the corresponding profile. (Paragraph 4, Article 96 of Federal Law No. 273)

International accreditation is the recognition by an authoritative international organisation of the compliance of a higher education institution, its set of programs or a separate educational program with certain international standards of quality of education.

International certification

A special type of accreditation is certification — in this case, the educational program is recognised as conforming to quality standards and providing training at the level necessary for its graduates to obtain professional certificates (either with subsequent passing of certification exams without additional training or with exemption from them).

Independent examination is a variant of external assessment of the quality of educational programs, a kind of "audit", which is carried out by an expert Commission consisting of professionals recognised in this scientific and/or subject area. Often, the selection of experts and the organisation of expertise is taken over by an external operator organisation in relation to the university. Was developed a methodology for evaluating and self-examining the educational program that is helpful to conduct an independent examination with the help of international experts.

By the same way

the analysis of the quality of education should be carried out in two directions: 1. analysis of the quality of education provided,

2. analysis of the quality of education received.

The first direction evaluates the quality of the services that the educational institution provides to society. This assessment is based on the traditional requirements of State educational standards of the appropriate level and 
training program. As the main groups of factors that form the quality assessment system in this direction, it should be noted:

the quality of writing of the curriculum, its compliance, quality content work educational programs, the combination of Federal and regional components, the level of teaching and technical equipment of educational process, advanced technology implemented in the educational process of pedagogical technologies, the level of staffing of the educational process,

- the level of material support and financing of the educational process,

- the level of development of the macro environment.

The second direction characterises the level of education actually received the level of training as a whole in the educational program, as well as in its individual cycles and disciplines. But the level of training is not the only factor that determines the quality of education actually received. It is also important to assess the dynamics of social and moral qualities of the student, his health, and social activity.

For the state, the key point is the degree of compliance with state educational standards, recognition at the international level. For an individual, the system of evaluating the quality of education includes such elements as the possibility of further employment, career growth, security, service, "escape" from the army, the ability to leave home, prestige, ease of passing the educational program, etc.

The complicate and hard process of Increase the Quality in HEIS has shown his results. The representation of Russian universities in international rankings has increased, mostly, it is possible to see the Moscow's universities with historically established brands, and four FU (Kazan Federal University, Ural Federal University, Southern Federal University, Far Eastern Federal University) and 13 National Research Universities.

In 2019, the QS global ranking included 1000 universities in the world. Twenty-five universities represented the Russian Federation and in 2020 by 28 universities.

\section{People's Friendship University of Russia a mirror of a multicul- tural global world}

Peoples ' Friendship University (RUDN) was founded on February 5, 1960 by the decision of the government of the USSR. On February 22, 1961, the university was named Patrice Lumumba - one of the symbols of the struggle of the peoples of Africa for independence. Students and scientists were free to study and research outside the political context, firmly following the great principles of friendship and mutual support. On February 5, 1992, the university was renamed the Peoples ' Friendship University of Russia by the decision of the Russian government. 
RUDN is the leader among Russian universities in terms of the share of international students in international rankings RUDN graduated a more than 150000 students from all countries world.

RUDN environment is multicultural. In each country, it is possible to find professor medicine workers economists and other experts that have been formed at RUDN.

Nowadays this peculiarity also RUDN should be attractive for students and this requires not only implementation of Quality of Education but also Increase of Student Services like campuses, a canteen for students and university staff libraries, student inclusion in the society places for study. In 2018 RUDN began constructing a hostel with a total area of 13302,7 square meters - a new approach to comfort for students and postgraduate students of the RUDN.

Taking in account the peculiarity of RUDN were in the same class is possible to have students from 5 different countries as a minimum there is a possibility to organise a cultural day where each student can represent their country through spectacles dance songs through an exposition of products of their land.

The strong point of RUDN is his graduates as through them the RUDN is recognised as an institution where students will acquire high skills and competencies useful for student's country of origin.

Contrary to other Russian Universities, RUDN shall not only meet the local/ national society requirement but mostly global society requirements.

According to UI Green Metric Ranking RUDN is among the leaders in categories "International students" and "Student-to-staff ration" and the greenest university in Russia.

RUDN University is one of the best world-class universities in Russia ranked by Times Higher Education: in 2018 RUDN was the only Russian University that to have risen by 100 positions in QS World University Rankings.

RUDN is also the first university in Russia to get 5 QS stars in 5 ranking categories.

RUDN campus is the greenest in Russia, and we are in TOP-100 of Times Higher Education Rankings in the number of international students.

In 2019 RUDN rose from the third group and entered the second group of the universities participating in the Project 5-100

The interuniversity's competition became more and more stressful and to keep the high level of the education process, and the university attractiveness RUDN focus on Quality Assurance, on Quality Evaluation and Quality Management.

The functioning of the Quality Management system (QMS) in RUDN is necessary to improve the efficiency of technology of knowledge transfer, skills (competencies) and the effectiveness of perception of these components of the pedagogical process by students. The existence of a quality management 
system, as well as the constant improvement of the quality of the activities of the mine is not the goal, but a necessary means of providing professional training of specialists. Quality management is carried out on a scientific, systematic basis, taking into account the innovative processes taking place in the international system of higher education. The quality management system is strictly formalised and can be documented and practically monitored in all major processes of organisation and implementation of training.

Data on Quality Assurance at RUDN has this characteristic:

- Independent quality control is carried out by student organisations.

- Quality management is based on the development of strategic and operational plans.

- The quality of education evaluation data in the RUDN are public and are published at the end of each academic year.

The main purpose of the RUDN quality management system (QMS) is to improve the quality of education at a modern international classical University 1. Ensures constant monitoring of the quality of education and its management by: - the University administration, - the management of faculties and educational institutions, - heads of departments and teachers, - as well as by students

2. Allows to have timely feedback on recognised achievements in basic and applied sciences, engineering and technology in training programs timely.

3. Facilitates the passage of the university's due diligence procedures by Rosobrnadzor.

4. it Is a prerequisite for international accreditation of 18 universities within the framework of the Bologna process.

Each year at RUDN are evaluated these indicators:

1The share of implemented international joint basic educational programs (double degree programs) and programs with modules of included training in $\%$ of the total number of programs.

2. The post NPR (Degree)

3. The number of monographs per NPR with academic degrees and titles per year, PCs.

4. The number of publications indexed in international databases Web of Science, on units NPR, PCs.

5. The number of publications indexed in international databases Scopus, on units NPR, PCs.

6 . The methodical activity of teachers.

7. Security of educational disciplines of UMK in electronic format in TUIS.

8. Protection in foreign languages.

9. The experts on the quality of education in RUDN of the number of employers, representatives of practice bases.

10. The amount of funding for research/R \& $\mathrm{d}$ to the total number of NPR of the University, reduced to the full rate, thousand rubles, external funding. 
11. The amount of funding for research/R \& $\mathrm{d}$ to the total number of NPR of the University, reduced to the full rate, thousand rubles, taking into account the own funds.

12. The weight of masters in the given contingent of students studying in the master's and bachelor's degree, $\%$.

13. Average student performance.

14. The score of the Satisfaction of students with the quality of education.

15. Employment.

Every year RUDN gives themselves a low threshold under which is forbidden to arrive.

Figure 1 RUDN indicator's achievement in 2018 (Source http://www.rudn.ru/education/learning-quality-system)

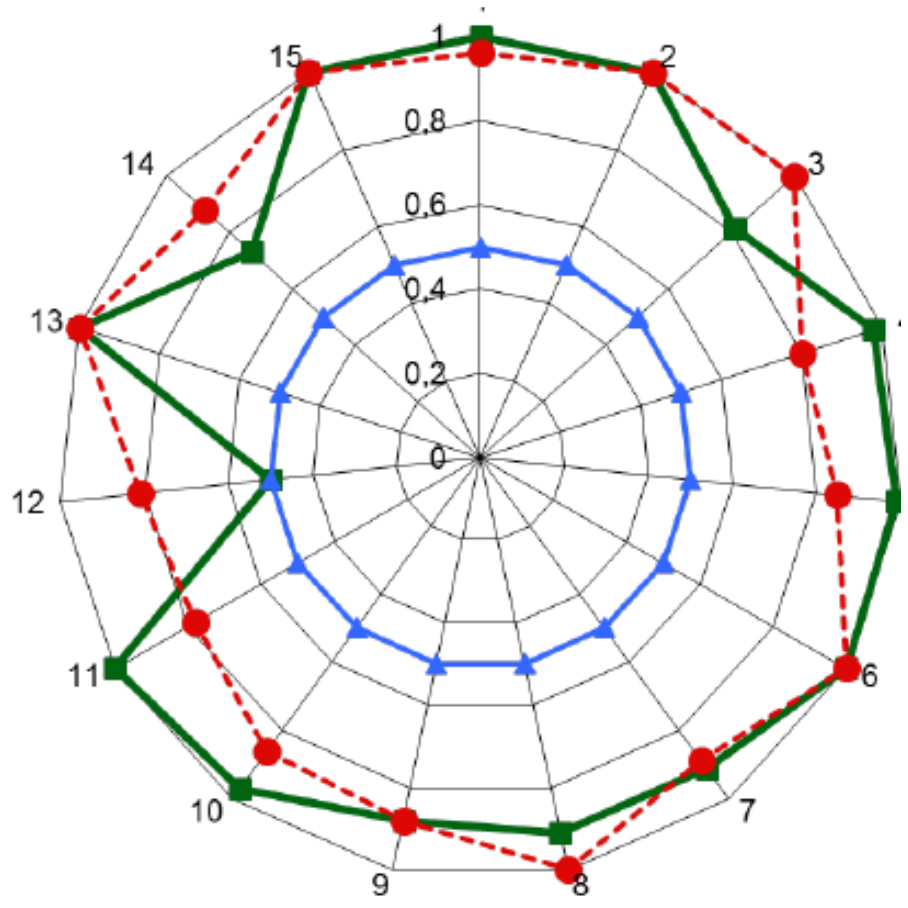

\begin{tabular}{|l|l|}
\hline & the minimum threshold \\
\hline- & RUDN planned achievement \\
\hline- & RUDN indicators for 2018 \\
\hline
\end{tabular}


As we can see from the figure above RUDN achieve quite all indicator's levels except the point 12 that is "the weight of masters in the given contingent of students studying in the master's and bachelor's degree."

The four point from quality indicators are dedicated to teacher's scientific activity. Even the number of monographs indicator is in line with planned achievement a little bit under red line are the indicators regarding the publication in indexed journal (4. The number of publications indexed in international databases Web of Science, on units NPR, PCs. 5. The number of publications indexed in international databases Scopus, on units NPR, PC). This fact can be explained by high cost of translation of academic issue and by high cost to publish in a high indexed journal in some journals the price can be more than 500 euro. For this reason, the University has a financing that can cover partially the expenditures to publish in Q1 and Q2 Journal.

Scientific activity is inextricably linked with the educational activity of the teacher. In all ratings, not only foreign but already in Russian, indicators of research performance are put at the forefront when determining the best universities.

The quality service implements the quality assurance program under the supervision of the University administration. The quality assurance service is a specialised division of the RUDN, whose task is solely to improve the efficiency of the institution's activities. In General, the quality service prepares and conducts internal audit procedures for the quality of training. The University quality service provides continuous monitoring of the quality of education in order to: a) improve the content of education, b) improve the organisation of training, C) increase the efficiency of all processes of knowledge transfer and perception.

\section{Conclusion}

The issue of preserving one's cultural and national identity in a globalising world remains open to many countries, including Russia. Researchers note the increasing contradictory influence of globalisation processes on Russian society, its economy, politics, science and education. Russian scientists state the current deformation of Russian science and education, their loss of classical forms and content, write about the growing gap between the professional competencies of Russian University graduates and the needs of the modern labour market and consider instrumentalisation of science and education as negative consequences of globalisation.

RUDN "product" or "good of use" is the global one and should meet the specific country's requirements.

RUDN is also focused on increase of academic staff. The quality of the teaching staff at the university is understood as ensuring a high level of 
teaching. A modern teacher should have a wide range of professional competencies, including excellent knowledge of their subject, constant professional self-improvement, high information communication The pedagogical competence of a teacher, in addition to the totality of knowledge and skills, is also the presence of research abilities necessary for him to perform the functions of teaching and educating students.

The mission of higher education is primarily to meet the specific needs of education and training of the individual, as well as the needs of the socioeconomic development of the community. The higher education institution fulfils that purpose only to the extent that it satisfies those requirements to a standard of quality that allows both the individual and society to perform in an environment globalised, characterised by competition and dynamism. Maintaining the standard is possible only under the conditions of the performance orientation of the academic activity, by improving continuous supply and results, efficient management, adequate financial policy rational use of resources and attracting new resources, by encouraging responsible attitude for all staff and students.

\section{References}

Bernhard, A. (2012). Quality assurance in an international higher education area: A case study approach and comparative analysis. Wiesbaden: VS Verlag fur Sozialwissenschaften, 40.

Frazer, M. (1997). Report on the modalities of external evaluation of higher education in Europe: 1995-1997. Higher Education in Europe, 22(3), 349-401.

Feigenbaum, A.V., (1999), The new quality for the twenty-first century, The TQM Magazine, Vol. 11 No. 6, pp. 376-383., doi.org/10.1108/09544789910287656 Juran J.M, Godfrey A B (1998) Juran's Quality handbook, McGraw-Hill, New York: Rumyantsev N, et al (2019) The mechanism for the recognition of quality and level of training graduates of law enforcements system requirements of the employer: new challenges, IOP Conf. Ser.: Earth Environ. Sci. 390012037

Spulber D (2005) University Quality Management: the internal audit system, in Stanaerdele si calitatea in invatamintul continuu, IIC Moldova, Chişinău, 2005

Stensaker, B., \& Harvey, L. (2006). Old wine in new bottles? A Comparison of public and private accreditation schemes in higher education. Higher Education Policy, 19(1), 65-85. Toffler A (1971) Future Shock. New York: Bantam, pp. 398-427

\section{Web references}

http://www.rudn.ru/education/learning-quality-system http://www.quality.edu.ru/

https://5top100.ru/ 